\title{
Versoberde pensioenen en de werkinzet van oudere werknemers : vervolgmeting (2010) VPL-onderzoek
}

Citation for published version (APA):

de Grip, A., \& Montizaan, R. M. (2011). Versoberde pensioenen en de werkinzet van oudere werknemers : vervolgmeting (2010) VPL-onderzoek. Researchcentrum voor Onderwijs en Arbeidsmarkt, Faculteit der Economische Wetenschappen. ROA Reports No. 6 https://doi.org/10.26481/umarep.2011006

Document status and date:

Published: 01/01/2011

DOI:

10.26481/umarep.2011006

Document Version:

Publisher's PDF, also known as Version of record

\section{Please check the document version of this publication:}

- A submitted manuscript is the version of the article upon submission and before peer-review. There can be important differences between the submitted version and the official published version of record.

People interested in the research are advised to contact the author for the final version of the publication, or visit the DOI to the publisher's website.

- The final author version and the galley proof are versions of the publication after peer review.

- The final published version features the final layout of the paper including the volume, issue and page numbers.

Link to publication

\footnotetext{
General rights rights.

- You may freely distribute the URL identifying the publication in the public portal. please follow below link for the End User Agreement:

www.umlib.nl/taverne-license

Take down policy

If you believe that this document breaches copyright please contact us at:

repository@maastrichtuniversity.nl

providing details and we will investigate your claim.
}

Copyright and moral rights for the publications made accessible in the public portal are retained by the authors and/or other copyright owners and it is a condition of accessing publications that users recognise and abide by the legal requirements associated with these

- Users may download and print one copy of any publication from the public portal for the purpose of private study or research.

- You may not further distribute the material or use it for any profit-making activity or commercial gain

If the publication is distributed under the terms of Article $25 \mathrm{fa}$ of the Dutch Copyright Act, indicated by the "Taverne" license above, 


\section{Versoberde pensioenen en de werkinzet van oudere werknemers \\ Vervolgmeting (2010) VPL-onderzoek}

Andries de Grip

Raymond Montizaan

ROA-R-2011/6 


\section{Colofon}

(C) Researchcentrum voor Onderwijs en Arbeidsmarkt (ROA). Niets uit deze uitgave mag op enige manier worden verveelvoudigd zonder voorafgaande schriftelijke toestemming van de directeur van het ROA.

\section{Researchcentrum voor Onderwijs en Arbeidsmarkt}

School of Business and Economics

Maastricht University

\section{Vormgeving}

ROA secretariaat, Maastricht

\section{Verkoop}

Researchcentrum voor Onderwijs en Arbeidsmarkt email: secretary-roa-sbe@maastrichtuniversity.nl website: www.roa.nl

ISBN: 978-90-532I-496-I

mei $201 \mathrm{I}$ 


\section{Inhoud}

Resumé $\quad$ v

1 Inleiding 1

2 Het effect van versoberde pensioenrechten op pensioengedrag 7

$\begin{array}{ll}2.1 \text { Natuurlijk experiment } & 7\end{array}$

2.2 Verwachte pensioenuitkering $\quad 8$

2.3 Verwachte pensioenleeftijd $\quad 8$

2.4 Levensloopregeling als middel om de versobering te compenseren 11

3 Wie treedt uit op 60 jarige leeftijd? $\quad 13$

4 Versoberde pensioenrechten en productief doorwerken 19

$\begin{array}{lll}4.1 & \text { Productief doorwerken } & 19\end{array}$

4.2 Persoonskenmerken en productief langer doorwerken 22

4.3 Percepties over het personeelsbeleid van werkgevers 25

5 Conclusies en aanbevelingen $\quad 27$

$\begin{array}{lll}5.1 \text { Samenvatting } & 27\end{array}$

$\begin{array}{ll}5.2 \text { Aanbevelingen } & 29\end{array}$ 



\section{Resumé}

Het toenemende aantal ouderen en het feit dat mensen steeds ouder worden maakt het onmogelijk om de oude pensioenrechten te handhaven. Bovendien zullen door de vergrijzing van de beroepsbevolking de komende jaren veel oudere werknemers de arbeidsmarkt verlaten. De overheid en sociale partners zijn zich in toenemende mate bewust van beide aspecten van de vergrijzingproblematiek. Dit heeft geleid tot een groeiend aantal maatregelen om de arbeidsmarktparticipatie van 6o-plussers te vergroten, voornamelijk door werknemers financieel te prikkelen om langer door te werken. Om langer door te kunnen werken is het vanzelfsprekend ook cruciaal dat de inzetbaarheid van oudere werknemers op peil blijft. Dit vereist dat oudere werknemers voldoende gemotiveerd blijven in hun werk en hun kennis en vaardigheden up-to-date te houden.

In dit rapport ${ }^{\mathrm{I}}$ wordt ingegaan op de vraag in welke mate werknemers reageren op een versobering in hun pensioenrechten en in hoeverre organisaties binnen de sector overheid en het onderwijs succesvol zijn in het stimuleren van het (productief) langer doorwerken van hun werknemers. Daarbij wordt specifiek gekeken naar de effecten van de invoering van het $A B P$ Keuzepensioen en het afschaffen van de FPU regeling in 2006 die beoogde de arbeidsmarktparticipatie van oudere werknemers te verhogen. Werknemers die geboren zijn in of na I950 hebben geen recht meer op de oude meer genereuze prepensioenrechten (FPU) en zullen daardoor langer moeten doorwerken, terwijl degenen die geboren zijn voor I januari 1950 nog gebruik kunnen maken van de oude FPU-regeling.

In samenwerking met het ABP heeft het ROA in 2007 een uniek onderzoekspanel gestart. Dit panel heeft betrekking op 7.000 voltijds werkende mannen in de sector overheid en onderwijs die geboren zijn in 1949 of 1950 . Dit onderzoekspanel maakt het mogelijk om onderzoek te doen naar het causale effect van het versoberen van pensioenen op het pensioengedrag van oudere werknemers en hoe werkgevers en werknemers reageren op de veranderingen in het pensioenstelsel. In dit rapport wordt

I. De bevindingen en meningen die worden gegeven in dit rapport komen uitsluitend voor rekening van de auteurs en reflecteren niet noodzakelijkerwijs die van het ABP. De auteurs willen de volgende leden van de begeleidingscommissie bedanken voor hun waardevolle suggesties: Rik Dillingh, Rob Euwals, Andre Nieuwenhuis en Olaf Sleijpen. 
verslag gedaan van de resultaten van de enquête die in 2010 aan het panel is voorgelegd. Het gaat hier om de vierde enquête die is uitgezet in het bovengenoemde panel. ${ }^{2}$

\section{Alternatieve routes voor vervroegde uittreding}

Veel werknemers die geboren zijn in 1950 denken alsnog vervroegd met pensioen te gaan en spreken daartoe vooral de levensloopregeling aan om dit verwezenlijken. Als werknemers de schok in hun pensioenrechten volledig zouden willen compenseren, dan zouden zij één jaar en één maand langer door moeten werken. Zij denken echter maar vier maanden langer door te werken. Een interessant gegeven is dat dit verschil in de verwachte pensioenleeftijd tussen degenen die in 1949 of in 1950 geboren zijn in de afgelopen jaren niet significant is toegenomen. Dit betekent dat de vervanging van de FPU door het ABP Keuzepensioen slechts in beperkte mate zal leiden tot een verhoogde arbeidsmarktparticipatie en dat de financiële prikkels om langer door te werken dus slechts in beperkte mate effectief zijn voor degenen die in 1950 geboren zijn. Voor jongere cohorten die geen aanspraak kunnen maken op de verhoogde bijdrage aan de levensloopregeling, kan daarentegen verwacht worden dat de versobering van hun pensioenrechten een grotere impact zal hebben op hun pensioenleeftijd. Overigens blijkt ook dat dat werknemers die geboren zijn in 1949 of 1950 momenteel later met pensioen denken te gaan dan dat ze in 2007 dachten, ongeacht onder welk pensioenregeling zij vallen. Aangenomen mag worden dat dit een reactie is op de toegenomen onzekerheid over de hoogte van de toekomstige pensioenuitkeringen.

\section{Wie ging met FPU in 2010?}

Het jaar 2010 is het eerste jaar waarin er sprake is van een substantiële uitstroom vanuit de 1949-groep naar de FPU. De groep mensen die met pensioen gaat op 60 jarige leeftijd heeft zeer specifieke kenmerken. Analyses tonen aan dat mensen in deze groep doorgaans een hoger pensioen ontvangen, meer dienstjaren hebben bij de overheid of het onderwijs, lager opgeleid zijn en minder vaak getrouwd zijn. Bovendien blijkt dat het grootste deel van de mensen die vervroegd uittraden werkzaam was bij provincies, gemeenten of bij de organisaties die vrijwillig zijn toegetreden bij het ABP.

Er moet echter ook worden opgemerkt dat met FPU gaan nog niet betekent dat mensen definitief zijn gestopt met werken. Voor meer dan helft van de werknemers die in het afgelopen jaar met FPU zijn gegaan geldt dat zij met deeltijdpensioen zijn gegaan.

2. Voor een verslag van de belangrijkste uitkomsten van de derde meting, zie: Andries de Grip, Raymond Montizaan, (2010). Langer doorwerken, werksituatie en productiviteit. Vervolgmeting (2009) VPL-onderzoek, ROA-R-20Io/8, Maastricht. 


\section{Werknemers die langer door moeten werken zijn minder productief}

In voorgaande rapporten is al vastgesteld dat werknemers die door de verslechtering van hun pensioenrechten gedwongen worden om later met pensioen te gaan, of een lagere pensioenuitkering te accepteren, nog steeds minder tevreden zijn met hun leven, minder tevreden zijn met hun baan en vaker depressief zijn. Daardoor is het zeer waarschijnlijk dat de vervanging van de FPU door het ABP Keuzepensioen een negatief effect heeft op de productiviteit van oudere werknemers. Om hier meer inzicht in te krijgen zijn goede gegevens over de specifieke werkzaamheden die oudere werknemers uitvoeren van cruciaal belang. Daarom is in dit rapport nader onderzocht wat het effect is van de versobering van de pensioenrechten op de mate waarin werknemers andere werkzaamheden zijn gaan doen om op die manier langer door te kunnen werken. Ook is gekeken naar de stress die zij ervaren in hun baan. Het blijkt dat werknemers die langer door moeten werken in de afgelopen vijf jaar relatief minder tijd zijn gaan besteden aan het leidinggeven en de supervisie van andere werknemers of aan het oplossen van complexe taken. Bovendien heeft de I950-groep tijdens hun werk minder vaak persoonlijk contact met mensen buiten hun organisatie. Dit kan erop duiden dat werkgevers een beleid voeren gericht op het ontlasten van werknemers die langer door moeten werken door belastende leidinggevende en communicatieve werkzaamheden uit hun takenpakket te halen. Het bestaan van een dergelijk ontziebeleid wordt bevestigd doordat we zien dat werknemers die in 1950 geboren zijn minder werkstress ervaren en minder vaak overuren zijn gaan maken.

Anderzijds blijkt ook dat de persoonskenmerken van oudere werknemers belangrijk zijn voor hun reactie op de versobering in hun pensioenrechten. Daarbij is het opmerkelijk dat werknemers die meer bevlogen en gemotiveerd zijn in hun baan zich de versobering van hun pensioenrechten sterk aantrekken. Juist deze werknemers verminderen het aantal onbetaalde overuren dat zij maken substantieel. Het feit dat vooral deze mensen het aantal onbetaald overuren zo sterk verlagen wordt veroorzaakt door gevoelens van oneerlijk behandeld te zijn. Zo blijkt dat de werknemers die sterk negatief reciproque zijn - de mate waarin mensen onaardig gedrag van anderen willen bestraffen - het sterkst reageren op de schok in het pensioenstelsel.

Het geven van financiële prikkels om langer door te werken lijkt daardoor op gespannen voet te staan met het belang om de productiviteit van oudere werknemers op peil te houden. Dit geldt specifiek voor de oudere werknemers die weinig tijd en mogelijkheden hebben om de schok in hun pensioenrechten te accommoderen. Een belangrijke conclusie die hieruit kan worden getrokken is dat een effectief beleid gericht op de duurzame inzetbaarheid van oudere werknemers niet uitsluitend gericht moet zijn op het vergroten van de financiële prikkels om langer door te werken. Een goed active ageing beleid is cruciaal om de demotiverende werking van financiële maatregelen te compenseren en de productiviteit van oudere werknemers die net buiten de boot vallen op peil te houden. Het blijkt echter dat oudere werknemers vrij negatief oordelen over het door hun werkgever gevoerde personeelsbeleid. Werkgevers 
zetten zich volgens de werknemers te weinig in om oudere werknemers langer aan het werk te houden. De percepties van werknemers over het personeelsbeleid van hun werkgever zijn in 2010 niet verbeterd. 


\section{Inleiding}

De arbeidsmarktuittrede van oudere werknemers in de overheid en het onderwijs is sinds een aantal jaren drastisch aan het veranderen. Werknemers zullen zich moeten instellen op een verlenging van hun loopbaan met op zijn minst een aantal jaren en moeten zich afvragen hoe ze dat op een gemotiveerde, plezierige, gezonde en productieve wijze kunnen doen bij hun huidige werkgever, of elders. Het langer doorwerken van oudere werknemers heeft vanzelfsprekend ook grote gevolgen voor hun werkgevers. Deze zullen zich moeten instellen op een situatie waarin er in hun organisatie meer 6o-plussers aan het werk zijn, maar ook op een grotere variatie in de uittredingsleeftijden als gevolg van de introductie van flexibelere pensioenregelingen, zoals het ABP Keuzepensioen. Bovendien zullen werkgevers zich moeten beraden op welke wijze zij hierop reageren. Daarbij gaat het om de vraag op welke manier zij uiteenlopende groepen werknemers gemotiveerd, gezond en productief aan het werk kunnen houden dan wel naar ander werk kunnen toe leiden. Bovendien speelt daarbij de vraag in hoeverre de versoberingen van het pensioenstelsel een demotiverende werking hebben op oudere werknemers.

Voor alle subsectoren binnen de overheid en het onderwijs is dat een vraag die steeds urgenter wordt. De overheid en het onderwijs behoren tot de meest vergrijsde sectoren van de Nederlandse economie. Dit geldt met name voor de sectoren beroepsen volwasseneneducatie, hoger beroepsonderwijs, primair en voortgezet onderwijs, provincies en water, energie en nutsbedrijven. Door de leeftijdsstructuur zal de arbeidsmarktuitstroom in deze sectoren vanwege pensionering in de komende jaren sterk toenemen. Hierdoor zal met name het onderwijs over enkele jaren met grote knelpunten in de personeelsvoorziening worden geconfronteerd. Vooral voor de werknemers in de leeftijden van 45-60 jaar zijn de veranderingen (afschaffing VUT, prepensioen e.d.) groot en aangenomen mag worden dat voor deze groep de spilleeftijd van vrijwillige (pensioen-) uittreding zo'n twee tot vier jaar zal opschuiven ten opzichte van de huidige generatie 6o-plussers. Bovendien kan worden verwacht dat de variatie in de uittredingsleeftijden sterk zal toenemen als gevolg van de toegenomen flexibiliteit die is geïntroduceerd in de pensioenregelingen. 
Vanaf de jaren '9o is er sprake van een groeiend aantal maatregelen en initiatieven om de arbeidsmarktparticipatie van oudere werknemers te vergroten en de vergrijzingsproblematiek tegen te gaan, onder meer door werknemers te stimuleren om langer door te werken. De beleidsagenda is in feite opgedeeld in twee aandachtsvelden:

I. een participatie-agenda

2. een productiviteitsagenda

De participatie-agenda heeft betrekking op het beleid dat gericht is op een hogere arbeidsparticipatie (van alle leeftijdscohorten) en bevat vooral maatregelen die mensen financieel prikkelen om langer op de arbeidsmarkt actief te blijven. Voorbeelden van dergelijke maatregelen zijn de afschaffing van de VUT en het prepensioen, het actuarieel neutraal maken van pensioenschema's en de striktere toelatingseisen voor arbeidsongeschiktheidsuitkeringen.

De productiviteits-agenda is daarentegen meer gericht op het van de grond krijgen van een levensfasebewust ('active ageing') personeelsbeleid, met het doel om de duurzame inzetbaarheid van het oudere personeel te vergroten. Dit beleid gaat uit van maatwerk om zo een werkomgeving te creëren die mensen stimuleert om te blijven doorwerken. Terwijl de financiële prikkels vervroegde uittreding duurder maken, is active ageing beleid bedoeld om mensen intrinsiek te motiveren om langer door te werken. Terwijl de participatie-agenda zich dus beperkt tot het stimuleren van het arbeidsaanbod van ouderen, gaat de productiviteitsagenda een stap verder door zich te richten op een duurzame en productieve arbeidsdeelname van ouderen.

In vergelijking met de participatie-agenda heeft de productiviteitsagenda echter pas vrij laat aandacht gekregen. De Raad voor het Overheidspersoneelsbeleid (ROP) benadrukte in het advies "Vluchten kan niet meer" (2005) de relevantie van een active ageing beleid voor de overheid en het onderwijs. Daaropvolgend heeft de regering in 2007 in het beleidsprogramma 2007-20II "Samen leven, samen werken" expliciet een passage opgenomen waarin zij aangeeft dat het kabinet contact wil hebben met de sociale partners om leeftijdsbewust personeelsbeleid te stimuleren. Enkele aandachtpunten uit het beleidsplan 2007-20IO zijn daarbij reeds concreet uitgewerkt, zoals in het project Iedereen doet mee en in het Actieteam Talent45+, maar deze projecten richten zich echter uitsluitend op de participatie-agenda. Zeer recentelijk heeft de Europese Commissie (september 20IO) voorgesteld om het jaar 2012 uit te roepen als het Europese jaar van active ageing. Tot een nadere concretisering van de productiviteitsagenda is het echter nog niet gekomen.

In dit rapport staat de vraag centraal in welke mate werknemers reageren op een versobering van hun pensioenrechten en in hoeverre organisaties binnen de overheid en het onderwijs succesvol zijn in het stimuleren van het (productief) langer doorwerken van hun werknemers. Daarbij wordt specifiek gekeken naar de effecten van de invoering van het $A B P$ Keuzepensioen en het afschaffen van de FPU regeling in 2006 die beoogde de arbeidsmarktparticipatie van oudere werknemers te verhogen. Door deze wijziging 
in de pensioenrechten hebben werknemers die geboren zijn in 1950 (of later) geen recht meer op de oude meer genereuze prepensioenrechten (FPU) en zullen daardoor langer moeten doorwerken, terwijl degenen die geboren zijn voor I januari I950 nog gebruik kunnen maken van de oude FPU regeling. Ten opzichte van de voorafgaande rapporten wordt daarbij in meer detail ingegaan op de effecten van de versobering in pensioenrechten op de mate waarin werknemers specifieke taken uitvoeren in hun werk en op de stress die zij ervaren in hun baan. Tevens hebben wij in 2010 voor het eerst een substantiële uitstroom waargenomen van werknemers richting FPU. Dit biedt de mogelijkheid om nader te onderzoeken wat de kenmerken zijn van de werknemers in de overheids- en onderwijssector die op hun $60^{\text {ste }}$ al gebruik maken van de FPU regeling.

In het rapport wordt specifiek ingegaan op drie onderzoeksvragen:

I. In hoeverre stimuleren financiële prikkels het langer doorwerken en hebben werknemers hun verwachtingen aangepast na de schok in hun pensioenrechten?

2. Wat zijn de mogelijke negatieve effecten van financiële prikkels op de productiviteit van oudere werknemers?

3. In hoeverre hebben werkgevers in de sector overheid en het onderwijs een active ageing beleid ontwikkeld om de mensen met versoberde pensioenrechten intrinsiek te motiveren om langer door te werken?

Om deze vragen te beantwoorden zullen wij gebruik maken van een unieke dataset waarin uitgebreide informatie beschikbaar is over de werkmotivatie, het takenpakket, pensioenrechten en het verwachte inkomen na pensionering van oudere werknemers binnen de overheid en het onderwijs. De dataset bestaat uit een combinatie van survey data met administratieve data van het $\mathrm{ABP}$ en is gebaseerd op vier enquêtes die zijn gehouden in de jaren 2007-2010 onder een representatief panel van mannelijke full-time werknemers die zijn geboren in 1949 of 1950 . De steekproef is verder beperkt tot mannen die reeds sinds 1997 in de publieke sector werkzaam waren en niet vallen onder afwijkende regelingen. ${ }^{3}$

In 2007 bedroeg de bruikbare surveyrespons 7.019, waarvan 3.692 mannen die geboren zijn in 1950 en 3.327 mannen die geboren zijn in $1949 .{ }^{4}$ In 2008, 2009 en 2010 bestond de bruikbare respons uit respectievelijk 5.559, 6.62I en 6.652 individuen. Het unieke van deze dataset is dat de gegevens betrekking hebben op een homogene

3. Het merendeel van de mannelijke employees die geboren zijn in 1949 of 1950 zijn kostwinner terwijl vrouwen die geboren zijn in deze twee jaren vaak een onderbroken loopbaan hebben. In deze leeftijdsgroep hebben mannen gemiddeld genomen 28 jaar pensioen opgebouwd terwijl vrouwen maar 16 jaar hebben opgebouwd. Bovendien, is alleen een kleine selectieve groep van deze vrouwen nog steeds werkzaam (30\% van alle werknemers geboren in 1949 en 1950), waarvan $72 \%$ ook nog eens werkt in een parttime baan (CBS, Statline 2005). Daarbij geldt eveneens dat deze groep vrouwen niet representatief is voor de jongere cohorten.

4. Om het onderscheid in de pensioenrechten zo scherp mogelijk te houden tussen werknemers die geboren zijn in 1949 of 1950 , blijven de mensen die onder een FLO regeling vallen, zoals degenen die werkzaam zijn bij de politie, brandweer of ambulancedienst evenals militair personeel in dit onderzoek buiten beschouwing. 
groep werknemers van vrijwel dezelfde leeftijd met verschillende pensioenrechten vanwege de invoering van het $\mathrm{ABP}$ Keuzepensioen. Werknemers die geboren zijn in of na I950 hebben geen recht meer op de oude meer genereuze prepensioenrechten (FPU) en zullen daardoor langer moeten doorwerken, terwijl degenen die geboren zijn voor of in 1949 nog gebruik kunnen maken van de oude FPU-regeling.

Vanwege het experimentele karakter van de data is het mogelijk om de causale relatie te analyseren tussen aan de ene kant de (exogene) veranderingen in de pensioenrechten en aan de andere kant de productiviteit van degenen die hierdoor langer doorwerken en het verwachte uittredegedrag. ${ }^{5}$ Zonder het experimentele karakter en de panelstructuur zou het moeilijk zijn om causale verbanden vast te kunnen stellen, omdat het dan onduidelijk is of de anticipatie van werknemers op een bepaalde pensioenleeftijd hun productiviteit en werkinzet beïnvloedt, of dat een hoge productiviteit en werkinzet juist leidt tot uitstel van pensionering. In dit onderzoek ligt het causale verband echter vast: degenen die geboren zijn in 1950 zullen langer moeten doorwerken om dezelfde pensioenrechten op te bouwen als die van de mensen die geboren zijn in 1949. Voor de eerstgenoemde groep geldt bovendien dat vervroegd pensioneren voor de leeftijd van 65 jaar relatief meer geld kost naarmate iemand eerder wil stoppen met werken.

Een bijkomend voordeel van onze onderzoeksopzet is dat de data voor dezelfde personen beschikbaar zijn in vier opeenvolgende jaren. Het monitoren van de individuele medewerkers over een aantal jaren kan de pensioenplannen van de respondenten goed in kaart brengen. Ook maakt het onderzoek het mogelijk om de ontwikkeling van het active ageing beleid te analyseren. Hierdoor kunnen we zien in hoeverre werknemers die geen recht meer hebben op de FPU regeling in de loop van de tijd hun pensioenverwachtingen hebben bijgesteld of actie hebben ondernomen om hun pensioen aan te vullen naarmate zij dichter bij hun pensioen komen.

Dit rapport is als volgt opgebouwd. In Hoofdstuk 2 wordt ingegaan op de schok in het pensioenstelsel en het 'natuurlijk experiment' dat wordt benut om de bovenstaande vragen te beantwoorden. In navolging op eerdere rapporten wordt geanalyseerd wat de gevolgen van de financiële prikkels zijn op het verwachte uittredegedrag. Daardoor kan ook de dynamiek van de pensioenverwachtingen in de periode 2007-2010 in beeld worden gebracht. Tevens wordt er gekeken naar de mate waarin werknemers de financiële prikkels om langer door te werken (gedeeltelijk) compenseren door hun pensioenbesparingen te verhogen door gebruik te maken van deeltijdpensionering en de levensloopregeling. In Hoofdstuk 3 wordt geanalyseerd welke mensen in 2009 met FPU zijn gegaan. Hoofdstuk 4 analyseert of de financiële prikkels negatieve gevolgen hebben gehad op de productiviteit van de werkenden. Daarbij wordt er gekeken naar het effect van de financiële prikkels om langer te moeten doorwerken op het takenpakket van oudere werknemers en de werkdruk die zij ervaren. Bovendien wordt

5. Het onderscheid in de pensioenrechten tussen werknemers die in 1949 en I950 zijn geboren kan worden aangeduid als een 'natuurlijk experiment'. 
specifiek ingegaan op de vraag in hoeverre bepaalde persoonskenmerken van oudere werknemers van invloed zijn op deze effecten. In Hoofdstuk 5 vatten we de onderzoeksuitkomsten samen en geven wij enkele beleidsaanbevelingen. 



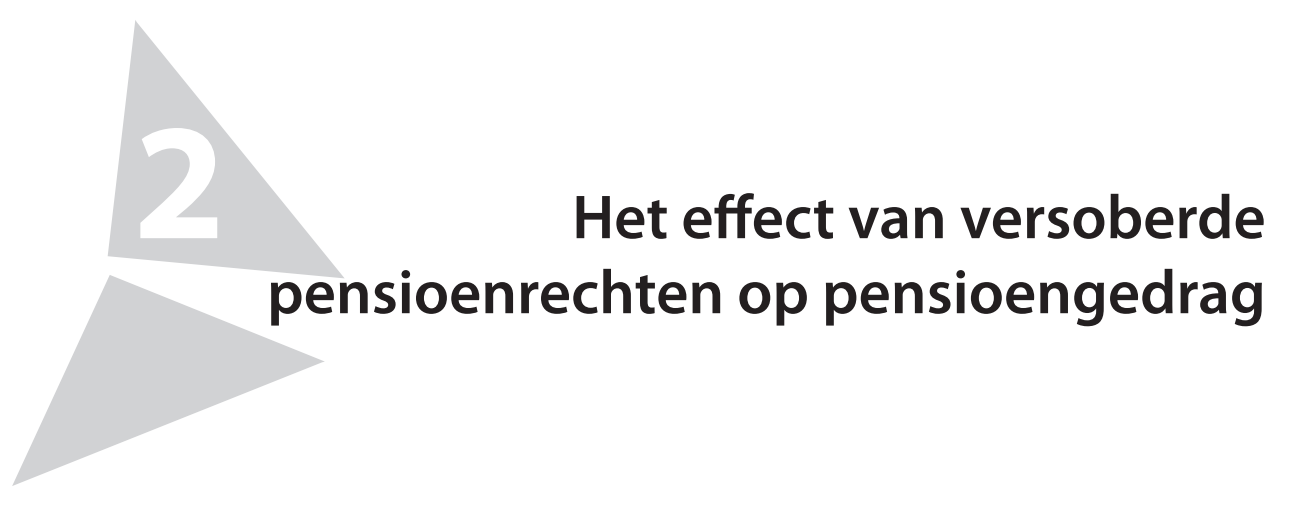

\subsection{Natuurlijk experiment}

In dit hoofdstuk gaan wij in op de effecten van de vermindering van de pensioenrechten op de pensioenverwachtingen. Het vervallen van de FPU rechten in combinatie met de invoering van het ABP Keuzepensioen kan vanuit onderzoeksperspectief worden gezien als een natuurlijk experiment, waarbij werknemers van vrijwel dezelfde leeftijd worden geconfronteerd met verschillende pensioenrechten. Hierdoor is het eenvoudig om het effect van financiële prikkels om langer door te werken op het gedrag van werknemers te analyseren. De werknemers die geboren zijn in 1950 vallen namelijk sinds I januari 2006 onder ABP Keuzepensioen en zullen noodgedwongen langer moeten doorwerken indien zij bij hun pensionering dezelfde pensioenuitkering wensen te ontvangen, terwijl de werknemers die geboren zijn in 1949 (en op I januari 2006 minstens Io jaar werkzaam waren bij de overheid of in het onderwijs) nog gebruik kunnen maken van de oude FPU regeling. Het nieuwe pensioensysteem geeft de werknemers die zijn geboren in 1950 een aantal prikkels om langer door te werken:

I. Zij worden geconfronteerd met een daling in hun pensioenuitkering tenzij ze later met pensioen gaan;

2. De hoogte van hun pensioenuitkering hangt in sterkere mate af van de leeftijd waarop zij met pensioen zullen gaan dan voor degenen die in 1949 zijn geboren.

3. Werknemers wordt de mogelijkheid geboden om tussen hun $60^{\text {ste }}$ en hun $70^{\text {ste }}$ met pensioen te gaan. In theorie is het dus mogelijk dat werknemers ook na hun $65^{\text {ste }}$ blijven doorwerken.

De implicaties van de nieuwe pensioenregeling zijn dat een werknemer met een 40 jarig dienstverband die geboren is in 1950 ongeveer één jaar en één maand langer moet werken om de oude norm van een pensioen van $70 \%$ van het middelloon te krijgen. Daarentegen kunnen werknemers die geboren zijn in 1949 en sinds I april 1997 continu hebben gewerkt bij een organisatie in de overheid of het onderwijs, bij een 40 jarig dienstverband op een leeftijd van 62 jaar en 3 maanden een pensioen krijgen dat gelijk is aan $70 \%$ van hun middelloon. 


\subsection{Verwachte pensioenuitkering}

Wat is het effect van de veranderingen in het pensioensysteem op de pensioenverwachtingen van werknemers die geboren zijn in 1949 of 1950. Tabel 2.I laat zien dat mensen die geboren zijn in 1950 een beduidend lagere uitkering verwachten indien zij op hun $62^{\text {ste }}$ met pensioen zouden gaan. Het verschil in de verwachte pensioenuitkering tussen de 1949 en 1950 groepen is in alle waarnemingsjaren statistische significant. We zien echter wel dat het verschil in de verwachte pensioenuitkering tussen beide groepen varieert over de tijd. In 2007 bedroeg het gemiddelde verschil 5,7\%-punt. Dit verschil wijkt nauwelijks af van het feitelijke verschil in pensioenrechten tussen de twee geboortejaren (6\%-punt). Daarentegen bedroeg het gemiddelde verschil in de verwachte pensioenhoogte tussen de beide leeftijdsjaren in 2008 slechts 3,7\%-punt. In 2009 en 2010 is het verschil tussen beide groepen echter weer toegenomen $(5,0 \%$-punt in 2009 en $5,8 \%$-punt in 2010).

Tabel 2.1

Impact van afschaffing FPU op de verwachte pensioenuitkering

\begin{tabular}{ccccc} 
& 1949 & 1950 & $\begin{array}{l}\text { Significantie } \\
\text { verschil 1949-1950 }\end{array}$ \\
Stel u zou met 62 jaar met pensioen gaan. Hoe hoog, denkt u dat uw & & \multicolumn{4}{c}{ pensioenuitkering } & dan zal zijn? In \% van uw netto salaris \\
2007 & 72,3 & 66,6 & $* * *$ \\
2008 & 72,1 & 68,4 & $* * *$ \\
\hline 2009 & 68,4 & 63,4 & $* * *$ \\
\hline 2010 & 65,8 & 60,0 & $* * *$
\end{tabular}

De verschillen in de pensioenuitkering van diegenen die geboren zijn in 1949 of 1950 zijn in alle jaren significant op het $1 \%$ niveau.

Het blijkt dat de financiële crisis die eind 2008 begon ook een effect heeft gehad op de pensioenverwachtingen. De tabel toont aan dat mensen die geboren zijn in 1950 als gevolg van de afschaffing van de FPU goed op de hoogte zijn van hun lagere pensioenrechten, maar laat ook zien dat de verwachte pensioenuitkering voor beide geboortejaren substantieel gedaald is. Waarschijnlijk is dit een reactie is op de toegenomen onzekerheid over de feitelijk latere pensioenuitkeringen. Zo heeft de financiële crisis en de toenemende levensverwachting geleid tot meer onzekerheid over de houdbaarheid van het huidige pensioenstelsel. Bovendien heeft de financiële crisis geleid tot een daling van de dekkinggraden van de pensioenfondsen in Nederland met als gevolg dat pensioenen momenteel niet geïndexeerd worden.

\subsection{Verwachte pensioenleeftijd}

Een belangrijke vraag is vervolgens in hoeverre de werknemers die in 1950 zijn geboren hebben ingespeeld op de schok in hun pensioenrechten. Zij kunnen er voor kiezen om langer door te werken om zo het gat in hun pensioenrechten te compenseren, maar de mogelijkheid bestaat eveneens dat zij hun pensioen niet uitstellen en genoegen nemen 
met een lagere pensioenuitkering. Ook is het mogelijk dat zij zelf zijn gaan bijsparen om hun pensioen weer op min of meer op dezelfde hoogte te brengen als voor de versobering van hun pensioenrechten.

Tabel 2.2 laat de impact zien van de afschaffing van de FPU op de verwachte pensioenleeftijd. Het blijkt dat de financiële prikkels in 2007 een sterk effect hebben gehad op de verwachte pensioenleeftijd.

\section{Tabel 2.2}

Impact van afschaffing FPU op verwachte pensioenleeftijd

\begin{tabular}{|c|c|c|c|}
\hline & 1949 & 1950 & $\begin{array}{l}\text { Significantie } \\
\text { verschil 1949-1950 }\end{array}$ \\
\hline \multicolumn{4}{|c|}{ Op welke leeftijd denkt u definitief te stoppen met werken? (gemeten in jaren) } \\
\hline 2007 & 62,6 & 63,5 & *** \\
\hline 2008 & 61,8 & 62,1 & $* * *$ \\
\hline 2009 & 63,1 & 63,4 & $* * *$ \\
\hline 2010 & 63,4 & 63,9 & $* * *$ \\
\hline
\end{tabular}

De verschillen in de verwachte pensioenleeftijd van diegenen die geboren zijn in 1949 of 1950 zijn in alle jaren significant op het $1 \%$ niveau.

Eén jaar na de hervorming dacht de gemiddelde werknemer die nog recht heeft op FPU uit te treden als hij 62 jaar en 7 maanden oud is. Daarentegen verwachten de werknemers die geboren zijn in 1950 gemiddeld genomen met pensioen te gaan als zij 63 jaar en 6 maanden oud zijn. Interessant is dat beide groepen op de leeftijd waarop zij met pensioen denken te gaan, indien zij 40 dienstjaren hebben, ongeveer een pensioeninkomen hebben ter hoogte van ongeveer $70 \%$ van het brutoloon.

Opvallend is dat zowel de werknemers die geboren zijn in 1949 als degenen die geboren zijn in 1950 begin 2008 de verwachte pensioenleeftijd naar beneden hebben bijgesteld. Daarbij is het verschil in de verwachte pensioenleeftijd tussen de mensen die geboren zijn in 1949 of 1950 nog maar drie maanden. In 2009 en 2010 is voor beide groepen de verwachte pensioenleeftijd echter weer toegenomen, waarschijnlijk als gevolg van het pessimisme dat is ontstaan door de economische crisis en de verslechtering van de dekkingsgraad van het ABP. In 2010 denken beide groepen ruim anderhalf jaar langer door te gaan werken dan dat ze in 2008 dachten. Echter, zowel in 2009 als in 2010 bleef het verschil in de verwachte pensioenleeftijd tussen beide geboortejaren beperkt tot slechts drie à vier maanden. Het effect van de afschaffing van de FPU op de verwachte pensioenleeftijd is dus in de loop der tijd dus kleiner geworden. Dit wijst erop dat degenen die geen recht meer hebben op FPU toch een lagere pensioenuitkering accepteren of dat zij de daling in hun pensioen zelf op individuele basis hebben aangevuld. ${ }^{6}$

6. Het onwaarschijnlijk dat de financiële crisis heeft bijgedragen tot het kleiner worden van het verschil in de verwachte pensioenleeftijd tussen de twee cohorten, omdat de crisis beide cohorten in gelijke mate heeft getroffen. De toename in de onzekerheid over de feitelijk latere pensioenuitkeringen (indexatie) is een probleem dat voor beide cohorten speelt. 
De Figuren 2.I en 2.2 geven een gedetailleerd beeld van het percentage werknemers dat op een bepaalde leeftijd met pensioen denkt te gaan. Opvallend is dat een groot deel van de werknemers die geboren zijn in 1950 hun pensioen denkt uit te stellen tot 65 jarige leeftijd (40\%), terwijl de pensioneringspiek op 63-jarige leeftijd veel kleiner is (I4\%). Dit betekent dat een grote groep werknemers door de afschaffing van de FPU langer gaat werken dan strikt noodzakelijk is om het door het door de ABP Keuzepensioen ontstane gat in hun pensioenrechten te dichten. Daarentegen denkt ruim $13 \%$ van de in 1950 geboren werknemers nog steeds op of voor hun $62^{\text {ste }}$ met pensioen te gaan.

Ook voor degenen die in 1949 zijn geboren valt er een piek te waar te nemen bij een verwachte pensioenleeftijd van 65 jaar, maar deze piek is significant kleiner (I8\%) dan bij de 1950 groep $(40 \%)$. Daarentegen verwachten relatief veel mannen die in 1949 geboren zijn met pensioen te gaan op de leeftijd van 62 jaar en vijf maanden, of als ze 63 jaar oud zijn. Ruim 46\% van alle werknemers die in 1949 zijn geboren denkt uit te treden rond deze leeftijden. Bovendien denkt nog eens I2\% op of voor hun $62^{\text {ste }}$ met pensioen te gaan. De pensioenverwachtingen van deze groep zijn derhalve meer in lijn met de spilleeftijd van 62 jaar en drie maanden waarop werknemers die geboren zijn in 1949 met een 40 jarig dienstverband met pensioen kunnen gaan tegen een vervangingsratio van $70 \%$ van hun middelloon, mits zij sinds I april 1997 zonder onderbreking in de overheidssector of het onderwijs hebben gewerkt. ${ }^{7}$

Figuur 2.1

Verwachte pensioenleeftijd: 1950 groep

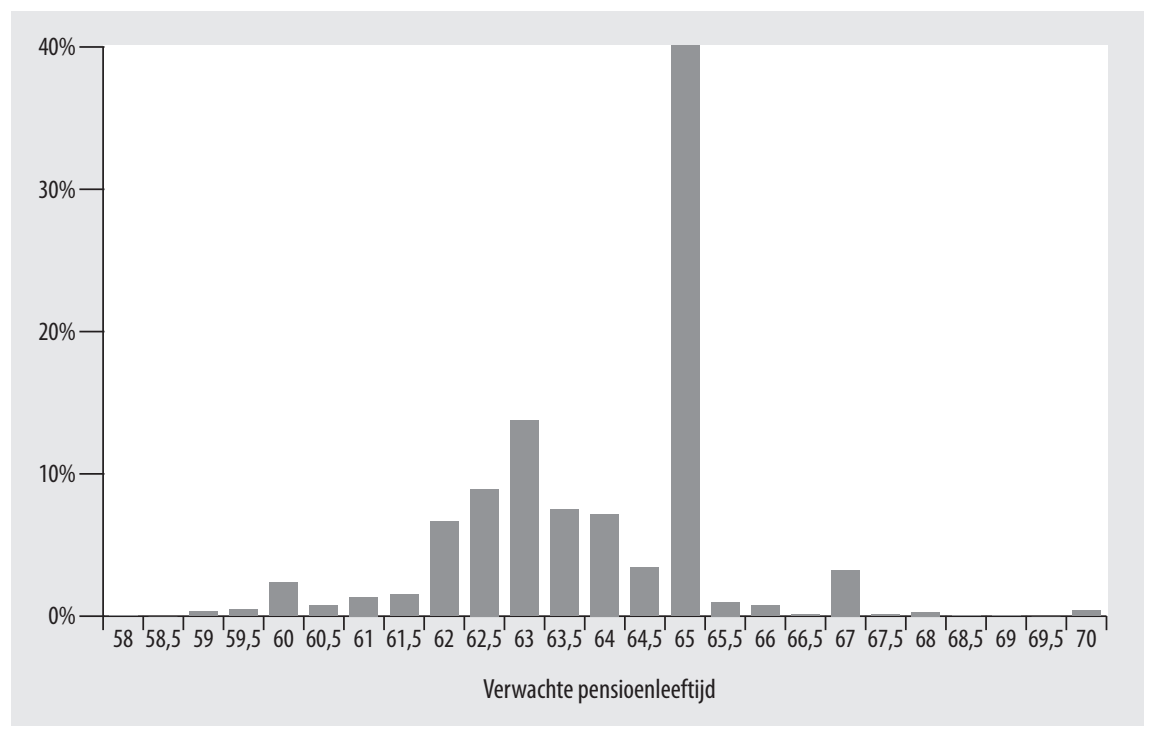

7. Tot I januari 2002 werden pensioenuitkeringen berekend op basis van het eindloon. Vanaf 2002 worden de pensioenuitkeringen van werknemers berekend op basis van het gemiddelde van het loon dat zij vanaf 2002 verdienen. 
Figuur 2.2

Verwachte pensioenleeftijd 1949 groep

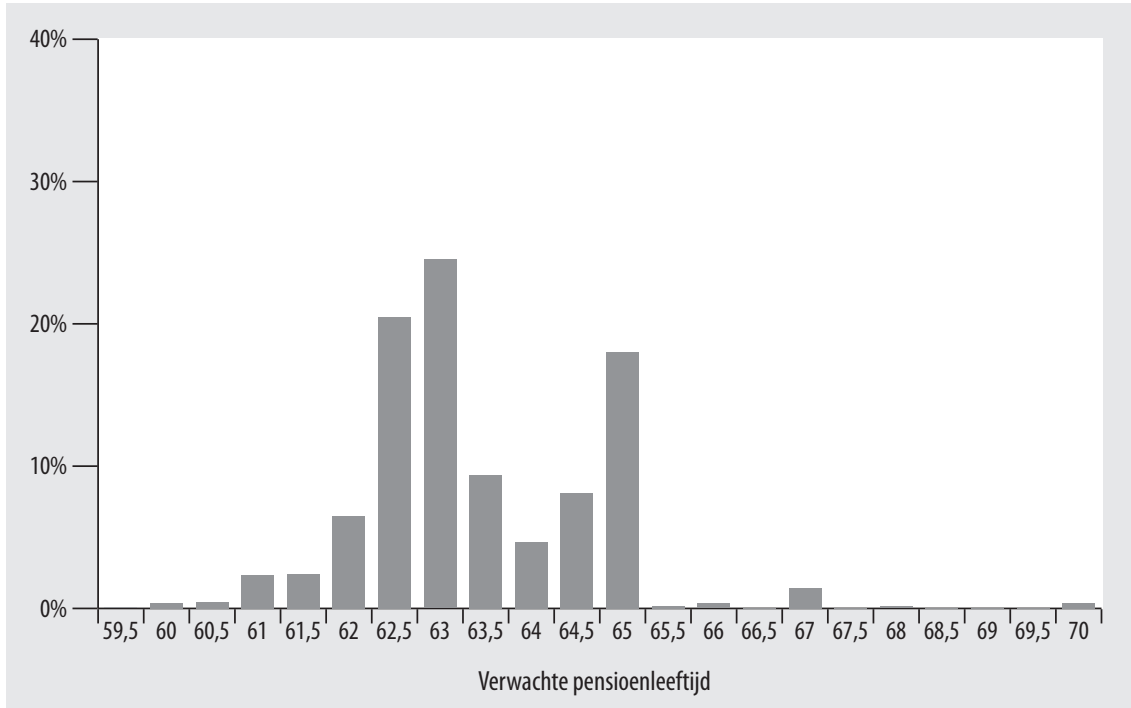

\subsection{Levensloopregeling als middel om de versobering te compenseren}

De in Tabel 2.2 gepresenteerde cijfers tonen aan dat de werknemers met verminderde pensioenrechten hun verwachte persioenleeftijd in de periode 2006-20I0 naar beneden hebben bijgesteld ten opzichte van degenen die geboren zijn in 1950. Het verschil tussen beide groepen is daarom nog maar vier maanden. Het lijkt er dus op dat werknemers met versoberde rechten hebben besloten om te gaan sparen om de schok in het pensioenrechten gedeeltelijk op te vangen.

Zoals al bleek in de rapportage op basis van de 2009 enquête hebben mensen die geboren zijn in 1950 wel vaker privaat pensioenproducten aangeschaft, maar de waarde van het door hen gespaarde bedrag is niet significant verschillend van het bedrag dat degenen die in 1949 zijn geboren voor hun pensioen hebben gespaard. Zoals Tabel 2.3 laat zien zijn de mensen met de verminderde pensioenrechten wel significant meer gaan sparen voor hun pensioen door gebruik te maken van de levensloopregeling. Onder de werknemers die geboren zijn in 1950 is de participatie in de levensloopregeling in zowel 2009 als in 2010 ruim 9\%-punt hoger dan bij degenen die in 1949 zijn geboren. Bovendien zijn hun investeringen in de levensloopregeling ook hoger.

Tabel 2.4 laat zien dat het percentage werknemers met versoberde pensioenrechten dat door hun investeringen in de levensloopregeling meer dan zeven maanden eerder met pensioen denkt te gaan in 2009 en 2010 aanzienlijk hoger is dan bij degenen die in 1949 zijn geboren. Gemiddeld genomen kunnen zij door hun investeringen in de 
levensloopregeling zeven tot twaalf maanden van hun pensioengat als gevolg van de vervanging van de FPU door het ABP Keuzepensioen overbruggen. Werknemers die geboren zijn in 1949 en hebben geïnvesteerd in de levensloopregeling kunnen gemiddeld genomen slechts vier tot zes maanden eerder uittreden.

Tabel 2.3

Impact van afschaffing FPU op investeringen in de levensloopregeling

\begin{tabular}{|cccc|} 
& & & Significantie verschil \\
& 1949 & 1950 & $1949-1950$ \\
\hline Maakt u gebruik of gaat u gebruik maken van de levensloopregeling? & & $* * *$ \\
\hline 2009 & 5,0 & 14,2 & $* * *$ \\
\hline 2010 & 5,7 & 14,9 &
\end{tabular}

Tabel 2.4

Aantal maanden dat iemand eerder met pensioen kan door deelname levensloopregeling

\begin{tabular}{|ccccc|} 
& & & \multicolumn{2}{c}{2010} \\
& 1949 & 1950 & 1949 & 1950 \\
\hline $1-3$ maanden & 31,9 & 13,2 & 44,0 & 14,4 \\
\hline $4-6$ maanden & 24,8 & 18,3 & 20,5 & 20,2 \\
\hline $7-12$ maanden & 25,5 & 31,3 & 20,5 & 32,5 \\
\hline $13-24$ maanden & 6,4 & 21,2 & 8,4 & 19,8 \\
\hline $25-36$ maanden & 6,4 & 10,1 & 4,8 & 8,5 \\
\hline 36 maanden of meer & 5,0 & 6,0 & 1,8 & 4,7 \\
\hline & 100 & 100 & 100 & 100 \\
\hline
\end{tabular}

De tabel laat echter ook zien dat er tussen 2009 en 2010 sprake is van een lichte daling in het aantal maanden dat werknemers in beide geboortejaren kunnen opnemen in het kader van de levensloopregeling. Gemiddeld genomen denken beide groepen in 20 Io ongeveer één maand minder op te bouwen met de levensloopregeling dan ze in 2009 nog dachten. Dit kan duiden op een meer realistische kijk van de respondenten op de opbrengst van hun investering in de levensloopregeling. Anderzijds is het mogelijk dat de economische crisis ook heeft geleid tot een daling in de levensloopbesparingen. 


\section{Wie treedt uit op 60 jarige leeftijd?}

In 2010 was er voor het eerst sprake van een substantiële arbeidsmarktuitstroom vanuit de 1949 groep naar de FPU. Tabel 3.I laat zien dat bijna 8\% van de werknemers die geboren zijn in 1949 een FPU uitkering hebben aangevraagd op 60 jarige leeftijd. Van deze groep heeft echter maar $47 \%$ de arbeidsmarkt helemaal verlaten: Bijna $53 \%$ van alle FPU aanvragen heeft betrekking op een deeltijdpensioenaanvraag. Hieruit blijkt dat deeltijdpensionering in korte tijd een populaire manier van uittreden is geworden, met als voordeel dat een grote groep ouderen nog gedeeltelijk blijft participeren op de arbeidsmarkt.

Tabel 3.1

Uittrede FPU-ers

\begin{tabular}{|cc|}
\hline Percentage FPU aanvragen 2010 & 1949 \\
\hline Deeltijdpensioenaanvragen 2010 (als percentage van totaal aantal FPU-aanvragen) & 7,8 \\
\hline
\end{tabular}

Tabel 3.2 onderstreept nog eens de sterke toename in de populariteit van deeltijdpensionering. Het percentage werknemers dat met deeltijdpensioen is of overweegt om in deeltijd te gaan werken is sinds 2009 met ruim 20\%-punt gestegen. Dit geldt overigens niet alleen voor de mensen die geboren zijn in 1949, maar ook voor het 1950 cohort. Desondanks is eveneens zichtbaar dat degenen met versoberde pensioenrechten minder vaak met deeltijdpensioen zijn gegaan. Uit een nadere analyse blijkt dat dit verschil niet het gevolg is van de verschillende pensioenrechten, maar van het leeftijdsverschil tussen beide groepen. Dit blijkt uit een regressie waarin naast de variabele die aangeeft in welk jaar men is geboren ook een continue leeftijdsvariabele (leeftijd in dagen) is toegevoegd als verklarende variabele. De coëfficiënt van de dummyvariabele is niet statistisch significant verschillend van nul. Dat betekent dat er geen significant verschil is in de mate waarin de beide leeftijdscohorten met deeltijdpensioen zijn gegaan. De coëfficiënt van de leeftijdsvariabele is daarentegen wel statistisch significant op I\%-niveau. Het blijkt dat de kans dat men een deeltijdpensioen aanvraagt met $0,5 \%$ stijgt met elke maand die men ouder wordt. 
Tabel 3.2

Deeltijdpensioen of deeltijdwerk

\begin{tabular}{|lcccc|}
\hline & 1949 & 1950 & Significantie verschil \\
Bent u op dit ogenblik met deeltijdpensioen of bent $\mathrm{u}$ in deeltijd gaan werken? & & & \\
\hline 2009 & 3,4 & 1,6 & $* * *$ \\
\hline 2010 & 25,2 & 21,8 & $* * *$ \\
\hline
\end{tabular}

De mensen die in 2010 op hun 6oste levensjaar met FPU zijn gegaan, hebben er voor gekozen om ruim voor de spilleeftijd van 62 jaar en drie maanden (gedeeltelijk) uit te treden. Voor deze mensen betekent dit dat zij, wanneer zij of hun werkgever niet hebben geïnvesteerd in additionele pensioenproducten, een pensioenuitkering zullen ontvangen die beduidend lager ligt dan de sociale norm van $70 \%$ van het middellooninkomen. Het is derhalve interessant om de specifieke kenmerken van deze groep gepensioneerden meer in detail te bekijken.

Tabel 3.3 bevat de resultaten van een regressieanalyse die laat zien wat de belangrijkste determinanten zijn van de kans op een FPU aanvraag in 2010 voor degenen die geboren zijn in 1949. Deze determinanten zijn met één jaar vertraging toegevoegd aan het model, zodat deze variabelen de situatie weergegeven op het moment dat alle respondenten nog werkzaam waren. De determinanten zijn vervolgens in vier categorieën ingedeeld:

I. de financiële situatie van de werknemer,

2. de baan en organisatiekenmerken,

3. persoonskenmerken,

4. de sector waarin de persoon werkzaam was in 2009.

Uit de tabel blijkt dat twee financiële variabelen een sterk significant effect hebben gehad op de kans om op 6o jarige leeftijd met (deeltijd)pensioen te gaan. Degenen die een hogere pensioenuitkering verwachten zijn vaker uitgetreden. De coëfficiënt geeft aan dat een IO\% hogere verwachte pensioenuitkering leidt tot een I\% hogere kans om uit te treden op 60 jarige leeftijd. Daarnaast blijkt dat het aantal jaren dat een werknemer heeft bijgedragen aan zijn pensioen sterk positief gecorreleerd is aan de uittredekans. Nadere analyses wijzen uit dat dit effect voornamelijk voor rekening komt van degenen die meer dan 40 jaar pensioenpremies hebben betaald aan het ABP. Deze mensen hebben nog recht op de dienstjarenovergangsregeling die er voor zorgt dat zij bij het bereiken van een specifiek aantal dienstjaren met FPU kunnen gaan tegen een uitkering die $70 \%$ van het middellooninkomen bedraagt, zelfs als zij nog niet 62 jaar en drie maanden zijn geworden. Het percentage werknemers dat hiervoor in aanmerking komt is echter zeer klein $(\mathrm{I}, 2 \%)$. 


\section{Tabel 3.3}

Determinanten uittrede op 60 jarige leeftijd (geboortecohort 1949)

\begin{tabular}{|c|c|}
\hline Afhankelijke variabele & Aanvraag FPU in 2010 \\
\hline \multicolumn{2}{|l|}{ Financiële situatie } \\
\hline \multirow[t]{2}{*}{ Verwachte pensioenuitkering op 62 jarige leeftijd } & $0.001^{* * *}$ \\
\hline & $(0.000)$ \\
\hline \multirow[t]{2}{*}{ Jaarinkomen (log) } & 0.016 \\
\hline & $(0.019)$ \\
\hline \multirow[t]{2}{*}{ Aantal jaren bijgedragen aan pensioenfonds } & $0.002^{* * *}$ \\
\hline & $(0.001)$ \\
\hline \multicolumn{2}{|l|}{ Baan en organisatiekenmerken } \\
\hline \multirow[t]{2}{*}{ Deeltijdfactor } & -0.059 \\
\hline & $(0.063)$ \\
\hline \multirow[t]{2}{*}{ Organisatiegrootte (log) } & $0.009^{* *}$ \\
\hline & $(0.004)$ \\
\hline \multicolumn{2}{|l|}{ Persoonskenmerken } \\
\hline \multirow[t]{2}{*}{ VMBO (HAVO / VWO is ref) } & $0.042^{*}$ \\
\hline & $(0.024)$ \\
\hline \multirow[t]{2}{*}{ MBO } & 0.025 \\
\hline & $(0.024)$ \\
\hline \multirow[t]{2}{*}{$\mathrm{HBO} / \mathrm{WO}$} & 0.026 \\
\hline & $(0.023)$ \\
\hline \multirow[t]{2}{*}{ Leeftijd in dagen (gedeeld door 100) } & $0.009^{* *}$ \\
\hline & $(0.000)$ \\
\hline \multirow[t]{2}{*}{ Huwelijkse staat ( 1 = getrouwd) } & $-0.025^{*}$ \\
\hline & $(0.015)$ \\
\hline \multirow[t]{2}{*}{ Aantal kinderen } & -0.000 \\
\hline & $(0.003)$ \\
\hline \multirow[t]{2}{*}{ Gezondheid (zelfgerapporteerd op 5-punts Likertschaal) } & -0.008 \\
\hline & $(0.006)$ \\
\hline \multicolumn{2}{|l|}{ Sector (Rijk is ref) } \\
\hline \multirow[t]{2}{*}{ Defensie Burger } & -0.033 \\
\hline & $(0.030)$ \\
\hline \multirow[t]{2}{*}{ Primair en voortgezet onderwijs } & 0.025 \\
\hline & $(0.017)$ \\
\hline \multirow[t]{2}{*}{ Rechterlijke macht } & -0.002 \\
\hline & $(0.055)$ \\
\hline \multirow[t]{2}{*}{ Gemeenten } & $0.085^{* * *}$ \\
\hline & $(0.018)$ \\
\hline \multirow[t]{2}{*}{ Provincies } & $0.209^{* * *}$ \\
\hline & $(0.033)$ \\
\hline \multirow[t]{2}{*}{ Waterschappen } & 0.015 \\
\hline & $(0.030)$ \\
\hline \multirow[t]{2}{*}{ Vrijwillige ABP toetreders } & $0.185^{* * *}$ \\
\hline & $(0.035)$ \\
\hline
\end{tabular}




\begin{tabular}{|lc|}
\hline Afhankelijke variabele & Aanvraag FPU in 2010 \\
\hline Wetenschappelijk onderwijs & $0.041^{*}$ \\
\hline Onderzoek en wetenschapsbeleid & $(0.021)$ \\
\hline Hoger beroepsonderwijs & 0.049 \\
\hline Academische ziekenhuizen & $(0.046)$ \\
\hline Beroeps en volwasseneneducatie & $0.045^{* *}$ \\
\hline Water, energie en nutsbedrijven & $(0.022)$ \\
\hline Overig & -0.002 \\
\hline Constante & $(0.028)$ \\
\hline Observaties & $0.036^{*}$ \\
\hline R-kwadraat & $(0.019)$ \\
\hline Deresultaten zinn gebaseerd & -0.018 \\
\hline & $(0.023)$ \\
\hline
\end{tabular}

De resultaten zijn gebaseerd op een lineair probability model. ${ }^{* *}$ significant op 1\%-niveau, ${ }^{* *}$ significant op 5\%-niveau, * significant op 10\%-niveau.

Verder blijkt dat de grootte van de organisatie waarin iemand werkzaam is van invloed is op de arbeidsmarktuittrede op 60 jarige leeftijd. Werknemers van grote organisaties hebben een grotere kans om vroeg met FPU te gaan. Het effect van de organisatiegrootte is echter zeer klein.

Wat betreft de persoonskenmerken valt op dat laagopgeleide werknemers (VMBOniveau of lager) vaker met FPU zijn gegaan (4,2\%). Een mogelijke verklaring hiervoor is dat laagopgeleide werknemers doorgaans meer routinematige banen hebben waarin zij meer repetitieve en mechanische taken uitvoeren en tevens vaker een hoge fysieke werkbelasting hebben die eveneens een negatieve invloed heeft op de gezondheidstoestand van deze werknemers. ${ }^{8}$ Verder vinden wij dat kleine leeftijdsverschillen binnen het geboortejaar eveneens van invloed zijn op de arbeidsmarktuittrede: de iets oudere werknemers zijn vaker met FPU gegaan. Ook blijkt dat mannen die getrouwd zijn minder vaak vervroegd uittreden dan alleenstaande mannen.

Ten slotte laten de coëfficiënten van de sectordummies zien dat het aantal werknemers dat op 6o jarige leeftijd FPU aanvraagt sterk uiteenloopt tussen de verschillende sectoren. De meeste FPU aanvragen komen van mensen die werkzaam zijn bij gemeenten, provincies of bij de organisaties die vrijwillig tot het $\mathrm{ABP}$ zijn toegetreden.

8. In additionele regressieanalyses vinden wij een sterk verband tussen het hebben van een VMBO achtergrond en het dagdeel dat men aan repetitieve en fysiek zware taken besteedt. Het dagdeel dat men besteedt aan taken is gemeten op een Io-puntsschaal. Het blijkt dat het hebben van fysiek zware taken een veel grotere invloed heeft op de arbeidsmarktuittrede dan het hebben van repetitieve taken. 
Bij de eerste twee sectoren is dit grotendeels toe te schrijven aan het feit dat er in deze sectoren naast de standaard FPU regeling nog aanvullende regelingen bestaan. Zo kunnen werknemers bij de provincies bijvoorbeeld gebruik maken van de FPU plusregeling, die het FPU inkomen aanvult als werknemers besluiten met deeltijd-FPU te gaan. Een interessant gegeven daarbij is dat aanvullende analyses, waarin interactieeffecten tussen de dummy voor laagopgeleiden en de sectordummies zijn opgenomen, laten zien dat de laagopgeleide werknemers bij de provincies vaker uittreden (coëfficiënt van het interactie-effect is 0,192 en standaardfout is 0,035). De sector vrijwillige $\mathrm{ABP}$ toetreders is een vrij heterogene sector die ruim 655 organisaties bevat die veelal geprivatiseerd zijn. De grootste werkgevers in deze sector zijn APG, Havenbedrijf Rotterdam, Stater, Driessen overheid plus, en de Onderwijs Service Groep. Vanwege de grote heterogeniteit van de organisaties in deze sector is het niet duidelijk waarom mensen hier in 2010 vaker een FPU uitkering hebben aangevraagd. 



\section{Versoberde pensioenrechten en productief doorwerken}

\subsection{Productief doorwerken}

In voorgaande rapporten is al vastgesteld dat werknemers die door de verslechtering van hun pensioenrechten gedwongen worden om later met pensioen te gaan, of een lagere pensioenuitkering te accepteren, minder tevreden zijn met hun leven, minder tevreden zijn met hun baan en vaker depressief zijn. ${ }^{9}$ Daardoor is het zeer waarschijnlijk dat de vervanging van de FPU door het ABP Keuzepensioen een negatief effect heeft op de duurzame inzetbaarheid van oudere werknemers. Om dit motivatieverlies tegen te gaan is het van groot belang dat de werkgevers in de overheids- en onderwijssectoren een motiverend personeelsbeleid voeren gericht op de persoonlijke ontwikkeling en het op peil houden van de vitaliteit van de werknemers met versoberde pensioenrechten.

In dit hoofdstuk staat de vraag centraal in hoeverre werkgevers de takenpakketten van oudere werknemers met versoberde pensioenrechten hebben aangepast om hen gemotiveerd aan het werk te houden. Verondersteld kan worden dat afwisseling in taken en het geven van taken die minder repetitief zijn en meer cognitieve vaardigheden vereisen kunnen bijdragen aan het behoud van iemands vitaliteit en duurzame inzetbaarheid. Eerdere studies toonden al aan dat ouderen zich gestimuleerd voelen om langer door te werken als zij vaker als specialist of deskundige worden ingezet en de mogelijkheid krijgen om collega's op te leiden. ${ }^{\text {IO }}$

Om meer inzicht te krijgen in het effect van het takenpakket op de motivatie om langer door te werken zijn goede gegevens over de specifieke werkzaamheden die oudere werknemers uitvoeren van cruciaal belang. Daartoe is in 2010 een blok met vragen over het takenpakket dat werknemers hebben toegevoegd aan de vragenlijst. De vragen zijn gebaseerd op een set met vragen uit de Princeton Data Improvement Initiative

9. Zie De Grip, A., en R. Montizaan, (20IO). Langer doorwerken, werksituatie en productiviteit. Vervolgmeting (2009) VPL-onderzoek, ROA-R-2010/8, Maastricht.

Io. Van Loo, J., De Grip, A., en R. Montizaan (2005), Active ageing bij Overheid en Onderwijs, ABP, Heerlen. 
(PDII) survey die internationaal gevalideerd is. ${ }^{\text {II }}$ De PDII heeft als doel om de fysieke, inter-persoonlijke en cognitieve dimensies van iemands baan te kenschetsen. Ook is gevraagd of er na de afschaffing van de FPU veranderingen hebben plaatsgevonden in de mate waarin men taken uitvoert in deze periode (de antwoordcategorieën van de vragen over veranderingen in de compositie van het takenpakket hebben betrekking op een 5 -puntsschaal die loopt van I (veel minder) tot 5 (veel meer).

\section{Tabel 4.1}

Versobering pensioenrechten en compositie takenpakket

\begin{tabular}{|c|c|c|}
\hline & $\begin{array}{c}\text { Impact } \\
\text { afschaffing FPU }\end{array}$ & $\begin{array}{l}\text { Standaard } \\
\text { Fout }\end{array}$ \\
\hline \multicolumn{3}{|l|}{ Dagdeel besteed aan (schaal 1-10): } \\
\hline Repetitieve taken & 0,055 & 0,116 \\
\hline Verandering repetitieve taken & 0,032 & 0,040 \\
\hline Fysieke taken & $-0,015$ & 0,084 \\
\hline Verandering fysieke taken & $-0,120$ & 0,040 \\
\hline Leiden van of supervisie over andere werknemers & $-0,312^{* *}$ & 0,133 \\
\hline Verandering leiden of supervisie andere werknemers & $-0,183^{* * *}$ & 0,046 \\
\hline $\begin{array}{l}\text { Problemen oplossen die minstens } 30 \text { minuten tijd kosten om te komen tot een } \\
\text { oplossing }\end{array}$ & $-0,109$ & 0,126 \\
\hline Verandering in problemen oplossen & $-0,101^{* *}$ & 0,042 \\
\hline \multicolumn{3}{|l|}{ Hoe vaak persoonlijk contact met (5-punts Likertschaal): } \\
\hline Klanten of cliënten & 0,012 & 0,064 \\
\hline Verandering klanten of cliënten & $-0,072^{*}$ & 0,040 \\
\hline Leveranciers of contractanten & $-0,096$ & 0,065 \\
\hline Verandering leveranciers of contractanten & $-0,094^{* *}$ & 0,037 \\
\hline Studenten of trainees & $-0,017$ & 0,072 \\
\hline Verandering studenten of trainees & $-0,011$ & 0,041 \\
\hline \multicolumn{3}{|l|}{ Cognitieve vaardigheden: } \\
\hline Hoe vaak problemen oplossen waarvoor wiskunde gebruikt (5-puntsschaal) & $-0,057$ & 0,077 \\
\hline Verandering gebruik wiskunde voor problemen & $0,068^{*}$ & 0,039 \\
\hline Wat is de lengte van het gemiddelde document (6-puntsschaal) & $-0,093$ & 0,058 \\
\hline Verandering lengte documenten & $-0,075^{*}$ & 0,039 \\
\hline
\end{tabular}

Uit Tabel 4.I blijkt dat werknemers die geboren zijn in 1950 niet minder vaak aangeven dat zij repetitieve of fysieke taken doen dan degenen die geboren zijn in 1949. Op dit punt lijkt er dus geen sprake van een personeelsbeleid dat er op gericht is om de werkmotivatie van mensen die langer moeten doorwerken op peil te houden. Opvallend is

II. Autor, D. en M. Handels, (2009). Putting Tasks to the Test: Human Capital, Job Tasks and Wages, MIT Discussion Paper. 
echter dat werknemers met versoberde pensioenrechten aangeven dat zij minder vaak leidinggevende taken uitoefenen dan degenen die geboren zijn in 1949. Het verschil op dit punt tussen de 1949 en I950 groep is aanzienlijk (I2,5\% van een standaarddeviatie in het dagdeel dat wordt besteed aan leidinggevende taken). Uit de antwoorden op de vraag of er na het versoberen van de pensioenrechten een verandering in de tijd die men besteedt aan leidinggeven heeft plaatsgevonden, blijkt ook dat werknemers die geboren zijn in 1950 aangeven dat men inderdaad sinds de afschaffing van het FPU minder tijd hieraan is gaan besteden. Een interessant gegeven hierbij is dat deze afname van leidinggevende taken op gespannen voet lijkt te staan met de wens van oudere werknemers om jongere collega's op te leiden.

Daarnaast geven degenen die in 1950 zijn geboren aan dat zij sinds de afschaffing van de FPU minder tijd zijn gaan besteden aan het oplossen van complexe problemen en ook minder werktijd besteden aan externe contacten met klanten, leveranciers, e.d.. Ook zijn de werknemers die geboren zijn in 1950 ten opzichte van degenen die geboren zijn in 1949 minder cognitieve taken gaan uitvoeren. Werknemers met versoberde pensioenrechten zijn relatief minder vaak lange documenten gaan lezen. Het lijkt er dus op dat werkgevers vooral een personeelsbeleid voeren dat de werknemers die langer door moeten werken ontlast van veeleisende taken in plaats van dat zij een activerend en een motiverend personeelsbeleid voeren. Hoewel de eisen die er aan oudere werknemers worden gesteld hierdoor wat lager worden, kan een dergelijk personeelsbeleid als schaduwzijde hebben dat het werk van mensen die langer moeten doorwerken minder interessant wordt.

Tabel 4.2 bevestigt het beeld dat werkgevers hun oudere werknemers met versoberde pensioenrechten eerder ontlasten dan dat zij hen actief blijven betrekken in het arbeidsproces. Werknemers met versoberde pensioenrechten rapporteren een significant lagere werkdruk dan degenen die in 1949 zijn geboren. Ze hebben ook minder last van storingen en afleiding tijdens hun werkzaamheden en geven minder vaak aan dat de hoeveelheid werk die zij hebben leidt tot tijdsdruk. In beide gevallen is het effect van de afschaffing van de FPU substantieel (IO\% tot II\% van een standaard deviatie in de werkdrukvariabele).

Tabel 4.2

Impact versobering pensioenrechten op werkdruk

\begin{tabular}{lcc} 
& Impact afschaffing FPU & Standaard fout \\
\hline Stress ervaren tijdens werkzaamheden & $-0,188$ & 0,120 \\
Storing en afleiding tijdens werkzaamheden & $-0,232^{*}$ & 0,124 \\
Hoeveelheid werk leidt tot tijdsdruk & $-0,278^{* *}$ & 0,120
\end{tabular}

De resultaten zijn gebaseerd op OLS regressies. ${ }^{* *}$ significant op $1 \%$-niveau, ${ }^{* *}$ significant op $5 \%$-niveau, * significant op 10\%-niveau. Leeftijd (in dagen) is aan elke regressie toegevoegd als controlevariabele. De antwoordcategorieën van alle drie de werkdrukindicatoren loopt van 1 (geen stress) tot 10 (maximale stress). 
Tabel 4.3

Impact versobering pensioenrechten op het aantal overuren

\begin{tabular}{lcc} 
& Impact afschaffing FPU & Standaard fout \\
\hline Dummyvariabele overuren & $-0,044^{*}$ & 0,026 \\
\hline Dummyvariabele onbetaalde overuren & $-0,037$ & 0,026 \\
Aantal onbetaalde overuren & $-1,780$ & 1,248 \\
De resultaten zijn gebaseerd op OLS regressies. ${ }^{* * *}$ significant op $1 \%$-niveau, & $* *$ significant op \\
5\%-niveau, ${ }^{*}$ significant op 10\%-niveau. Leeftijd (in dagen) is aan elke regressie toegevoegd als \\
controlevariabele.
\end{tabular}

Bovendien rapporteren werknemers met versoberde pensioenrechten dat zij minder overuren zijn gaan draaien. De coëfficiënt in Tabel 4.3 laat zien dat het percentage mensen dat overuren maakt $4,4 \%$ lager is in de 1950 groep. ${ }^{12}$

\subsection{Persoonskenmerken en productief langer doorwerken}

Het negatieve effect van de afschaffing van de FPU op de productiviteit zal niet voor alle mensen even groot zijn. Om de gedragsreactie van de werkenden op de versobering van hun pensioenrechten beter begrijpen, is het van groot belang om te zien welke mensen het sterkst reageren op de schok in de pensioenrechten. Daarbij is het bijvoorbeeld een belangrijke vraag of vooral de niet gemotiveerde mensen het meest worden ontzien door hun werkgever of juist degenen die normaliter zeer gemotiveerd zijn in hun werk.

In dit rapport kijken wij naar hoe twee specifieke persoonskenmerken de gedragsreactie van werknemers die in I950 zijn geboren hebben beïnvloed: de bevlogenheid van werknemers en de mate waarin werknemers negatief reciproque gedrag vertonen. Het begrip bevlogenheid ("engagement") komt uit de arbeidspsychologie en heeft betrekking op een positieve gevoelsmatige toestand die werknemers motiveert om hun werkdoelen beter en sneller te bereiken en daarmee het belang te dienen van de organisatie waarin zij werken. Bevlogenheid wordt ook wel beschouwd als de tegenhanger van burn-out en gedefinieerd als 'een positieve, werkgerelateerde psychische toestand die gekarakteriseerd wordt door vitaliteit, toewijding en absorptie'. ${ }^{\text {I3 }}$ Vitaliteit wordt daarbij gekenmerkt door een hoog niveau van energie, mentale veerkracht tijdens werk, inspanningsbereidheid en doorzettingsvermogen. Toewijding wordt gekenmerkt door een sterke betrokkenheid bij het werk, enthousiasme, trots en een gevoel van inspiratie en uitdaging. Als laatste wordt absorptie gekenschetst door het moeilijk los kunnen laten van het werk en het volledig er in opgaan waardoor de tijd voorbij vliegt. Deze drie aspecten van bevlogenheid liggen ten grondslag aan de

I2. Hoewel de coëfficiënten wel het juiste teken hebben, vinden we echter geen significante resultaten meer als we een onderscheid maken tussen onbetaalde en betaalde overuren of als wij een regressie schatten op het aantal onbetaalde overuren.

I3. Zie Schaufeli, W.B., Salanova, M., Gonzélez-Romá, V., en Bakker, A. B. (2002). The measurement of Engagement and burnout: A confirmative analytic approach. Journal of Happiness Studies, 3, 7I-92. 
korte versie van de Utrecht Work Engagement Schaal (UWES) die uitvoerig is getest op betrouwbaarheid en validiteit en is toegevoegd aan de vragenlijst. De schaal bestaat uit negen vragen:

Hoe vaak hebt u de volgende gevoelens over uw werk?

- Als ik werk bruis ik van energie

- Ik voel mij sterk en fit wanneer ik aan het werk ben

- Ik ben enthousiast over de inhoud van mijn werk

- Mijn werk inspireert mij

- Als ik s'ochtends opsta heb ik zin om naar mijn werk te gaan

- Wanneer ik intensief aan het werk ben, voel ik mij gelukkig

- Ik ben er trots op dat ik dit werk doe

- Ik ga helemaal op in mijn werk

- Ik laat me meeslepen door het werk waar ik mee bezig ben

De respondenten dienden vervolgens antwoord te geven op een 7-puntsschaal die loopt van I (nooit) tot 7 (altijd).

Tabel 4.4 laat het effect zien van de afschaffing van de FPU op de bevlogenheid van werknemers. De bevlogenheidindicator is geconstrueerd door het gemiddelde te nemen van de antwoorden op alle negen vragen. Uit de tabel blijkt dat werknemers in de 1950 groep niet minder bevlogen zijn dan degenen die geboren zijn in 1949. De coëfficiënt heeft wel een negatief teken, maar is niet statistisch significant. Als controleanalyses hebben wij eveneens regressiemodellen op de afzonderlijke bevlogenheidsvragen uitgevoerd. De coëfficiënt van de afschaffing van de FPU was in geen enkele regressie sterk statistisch significant. Alleen voor de inspiratie op het werk (coëfficiënt is $0, \mathrm{II} 3$ met standaardfout 0,069 ) en de mate waarin werknemers trots zijn op hun werk (coëfficiënt is $0, \mathrm{I} 22$ met standaardfout 0,073 ) vinden wij een zwak significant negatief effect van de versobering van de pensioenrechten.

\section{Tabel 4.4}

Impact van de versobering pensioenrechten op de bevlogenheid

$\begin{array}{ccc} & \begin{array}{c}\text { Impact } \\ \text { afschaffing FPU }\end{array} & \begin{array}{c}\text { Standaard } \\ \text { fout }\end{array} \\ \text { Bevlogenheid } & -0,077 & 0,056\end{array}$

De resultaten zijn gebaseerd op een OLS regressie. ***significant op 1\%-niveau, ${ }^{* *}$ significant op $5 \%$-niveau, *significant op 10\%-niveau. Leeftijd (in dagen) is toegevoegd als controlevariabele.

Daarentegen blijkt dat iemands bevlogenheid wel een belangrijke rol speelt bij de wijze waarop werknemers reageren op de versobering van hun pensioenrechten. Tabel 4.5 bevat de resultaten van regressies op de gemaakte overuren voor verschillende kwartielen van bevlogenheid. De eerste kolom bevat regressieresultaten voor de mensen die het minst bevlogen zijn in hun werk terwijl de vierde kolom de resultaten laat zien voor degenen die het meest bevlogen zijn. Het is zeer opmerkelijk dat 
juist de meest bevlogen werknemers met versoberde pensioenrechten hun werkinzet hebben verlaagd. Deze meest bevlogen werknemers met versoberde pensioenrechten geven aan dat ze in de maand voordat de enquête werd afgenomen significant minder vaak onbetaalde overuren hebben gemaakt dan degenen die geboren zijn in 1949. Bovendien is het aantal onbetaalde overuren van de 1950 -groep ook substantieel lager: Men werkte per maand gemiddeld bijna 5 uur minder onbetaald over dan degenen die in 1949 geboren zijn. ${ }^{\mathrm{I}}$

\section{Tabel 4.5}

Heterogene effecten op onbetaalde overuren: Bevlogenheid

\begin{tabular}{lcccc}
\hline Kwartiel bevlogenheid & $0-25$ & $25-50$ & $50-75$ & $75-100$ \\
\hline Dummyvariabele overuren & $-0,034$ & $-0,010$ & $-0,062$ & $-0,105^{* *}$ \\
\hline Dummyvariabele onbetaalde overuren & $-0,026$ & $-0,016$ & $-0,052$ & $-0,093^{*}$ \\
\hline Aantal onbetaalde overuren & $-1,246$ & 0,276 & $-2,734$ & $-4,854^{* *}$
\end{tabular}

De resultaten zijn gebaseerd op OLS regressies. ${ }^{* * *}$ significant op $1 \%$-niveau, ${ }^{* *}$ significant op $5 \%$-niveau, * significant op 10\%-niveau. Leeftijd (in dagen) is aan elke regressie toegevoegd als controlevariabele. De opdeling in kwartielen van bevlogenheid zijn afzonderlijk uitgevoerd voor de 1949 en 1950 groepen.

In eerste instantie lijkt dit resultaat contra-intuïtief. Immers, men zou juist verwachten dat de meest bevlogen mensen vanwege hun toewijding ten opzichte van hun baan hun werkinzet niet zouden verminderen. Het is echter ook goed mogelijk dat werknemers in ruil voor de bevlogenheid voor hun werk ook betrokkenheid en loyaliteit van hun werkgever verwachten. De kans bestaat dat werknemers de versobering van hun pensioenrechten als een breuk in de betrokkenheid van hun werkgever ervaren als deze hen niet actief bijstaat om hun duurzame inzetbaarheid op peil te houden of de versobering van hun pensioenrechten compenseert. De daling in de werkinzet van bevlogen werknemers zou in dat geval verklaard kunnen worden door negatief reciproque gedrag, dat is de mate waarin mensen onrechtvaardig gedrag van anderen willen bestraffen. ${ }^{\text {I5 }}$

De rol van negatieve reciproque gevoelens is onderzocht door gebruik te maken van de antwoorden op drie vragen die negatieve reciproque gevoelens meten: ${ }^{16}$ Kunt $\mathrm{u}$ aangegeven in hoeverre de onderstaande stellingen op u van toepassing zijn?

I4. Bevlogen mensen werkte gemiddeld genomen het meest over (twaalf onbetaalde overuren per maand). Ter vergelijking de minst bevlogen werknemers werkte maar zes uur over.

I5. Schmidt, K., en E. Fehr (2000). Theories of fairness and reciprocity; Evidence and Economic Applications, CESinfo Working Paper No. 403.

I6. De vragen zijn experimenteel gevalideerd door Perugini, M., M. Gallucci, F. Presaghi, en A. P. Ercolani (2003). The personal norm of reciprocity, European Journal of Personality, 17, 25I-283. Nadere informatie over deze maatstaf is te vinden in Montizaan, R., (2010). Pension rights, human capital development and well-being, Maastricht. 
- Als mij ernstig onrecht wordt aangedaan, dan zal ik kosten noch moeite sparen om mij te revancheren.

- Als iemand mij in een moeilijke positie brengt, dan zal ik met hem of haar hetzelfde doen.

- Als iemand mij beledigt, dan zal ik hem of haar met gelijke munt terugbetalen.

Respondenten konden antwoord geven op een 5-punts Likertschaal die loopt van I (zeer mee oneens) tot 5 (zeer mee eens). Door het gemiddelde te nemen over de drie antwoorden zijn deze vervolgens samengevoegd tot één indicator voor negatieve reciprociteit. Werknemers worden als zwak negatief reciproque gekenmerkt als hun score onder het gemiddelde van deze indicator ligt en zij worden als sterk negatief reciproque gekenmerkt als zij een score hebben die op of boven het gemiddelde ligt.

Tabel 4.6

Heterogene effecten op het aantal onbetaalde overuren: Bevlogenheid en negatieve reciprociteit

\begin{tabular}{lcccc} 
Kwartiel bevlogenheid & $0-25$ & $25-50$ & $50-75$ & $75-100$ \\
\hline Zwak negatief reciproque & 1,982 & $-2,513$ & $-4,967$ & $-3,191$ \\
\hline Sterk negatief reciproque & $-2,637$ & 1,693 & $-2,881$ & $-8,856^{*}$
\end{tabular}

De resultaten zijn gebaseerd op OLS regressies. *** significant op 1\%-niveau, ** significant op $5 \%$-niveau, * significant op 10\%-niveau. Leeftijd (in dagen) is aan elke regressie toegevoegd als controlevariabele.

Tabel 4.6 laat zien dat gevoelens van oneerlijk behandeld te zijn inderdaad een belangrijke determinant zijn van de gedragsreactie van bevlogen werknemers. De afschaffing van de FPU heeft geen significant effect gehad op het aantal onbetaalde overuren van werknemers die sterk bevlogen zijn maar niet sterk negatief reciproque zijn. Daarentegen is de coëfficiënt van de afschaffing van de FPU voor de bevlogen werknemers die sterk negatief reciproque zijn aanzienlijk groter. Bevlogen werknemers met versoberde pensioenrechten die negatief reciproque zijn hebben hun onbetaalde overuren met bijna negen uur per maand gereduceerd. Dit resultaat impliceert dat er mogelijk sprake is van een vertrouwensbreuk tussen de meest gemotiveerde werknemers en hun werkgever, met als gevolg dat juist de meest productieve werknemers hun werkinzet verlagen. Daarbij is het bovendien zeer opmerkelijk dat de werkgevers in de overheids- en onderwijssectoren deze daling in de werkinzet bewust of onbewust faciliteert door oudere werknemers te ontlasten in hun werk.

\subsection{Percepties over het personeelsbeleid van werkgevers}

In hoeverre hebben werkgevers in de overheid en het onderwijs volgens hun werknemers een sluitend active aging beleid ontwikkeld om degenen met versoberde pensioenrechten intrinsiek te motiveren om langer door te werken? Met andere woorden, zijn werkgevers in hun personeelsbeleid meer aandacht gaan geven aan diegenen die langer moeten gaan doorwerken? Om deze vraag te beantwoorden is in de enquête 
een tweetal vragen gesteld over het personeelsbeleid van de organisatie waarin iemand werkzaam is. Werknemers zijn gevraagd om het personeelsbeleid van hun werkgever in het algemeen te beoordelen en aan te geven in hoeverre hun werkgever zich meer is gaan inzetten om hen langer aan het werk te houden.

Tabel 4.7 laat zien dat veel werknemers zeer negatief zijn over het personeelsbeleid in hun organisatie. In 2010 denkt maar ongeveer $27 \%$ van alle werknemers dat hun werkgever een goed personeelsbeleid voert. Daarentegen, ruim 34\% beoordeelt het personeelsbeleid van hun werkgever als slecht of zeer slecht. We zien wel dat de tevredenheid over het personeelsbeleid iets is toegenomen sinds de invoering van het ABP Keuzepensioen. De toename in het percentage werknemers blijft echter zeer klein. Bovendien valt op dat dit negatieve oordeel over het gevoerde personeelsbeleid niet significant verschilt tussen de werknemers die nog met FPU kunnen en degenen met versoberde pensioenrechten. Hieruit blijkt dat werkgevers in de overheid en het onderwijs nog niet succesvol zijn om het oudere personeel, dat is geconfronteerd met een verslechtering van hun pensioenrechten, meer intrinsiek te motiveren voor hun werk door middel van een goed active aging beleid.

\section{Tabel 4.7}

Impact van afschaffing FPU op het personeelsbeleid

\begin{tabular}{|c|c|c|c|}
\hline & 1949 & 1950 & $\begin{array}{l}\text { Significantie verschil } \\
1949-1950\end{array}$ \\
\hline \multicolumn{4}{|l|}{ Tevredenheid over het personeelsbeleid } \\
\hline 2007 & 21,6 & 22,3 & \\
\hline 2008 & 22.9 & 27,7 & \\
\hline 2009 & 27,8 & 26,3 & \\
\hline 2010 & 27,8 & 26,6 & \\
\hline \multicolumn{4}{|c|}{ Inzet werkgever om werknemers langer aan het werk te houden } \\
\hline 2007 & 11,9 & 12,1 & \\
\hline 2008 & 10,6 & 10,4 & \\
\hline 2009 & 9,9 & 10.8 & \\
\hline 2010 & 14,1 & 13,7 & \\
\hline
\end{tabular}

Daarnaast zien we dat slechts I4\% van alle werknemers aangeeft dat hun werkgever zich meer is gaan inzetten om hen langer aan het werk te houden, terwijl ruim 50\% van alle werknemers aangeeft dat dit (volstrekt) niet het geval is. Het percentage werknemers dat een verhoogde inzet van hun werkgever waarneemt om hen aan het werk te houden is bovendien niet significant toegenomen sinds de afschaffing van de FPU en het percentage verschilt niet tussen degenen die geboren zijn in 1949 of 1950. 


\section{Conclusies en aanbevelingen}

\subsection{Samenvatting}

De effecten van de vergrijzing van de beroepsbevolking zullen de komende jaren steeds meer zichtbaar worden. Vooral in de sector overheid en onderwijs zijn er momenteel relatief veel 45-plussers werkzaam. Doordat de overheid en het onderwijs een veel sterker vergrijsd personeelsbestand kennen dan de private sector, zal de toekomstige arbeidsmarktuitstroom vanwege pensionering in deze sectoren ook veel groter zijn. Hoewel de economische crisis op de korte termijn de wervingsproblematiek enigszins verlicht, zal de toenemende uitstroom van de na-oorlogse babyboom generatie binnenkort al grote gevolgen hebben voor de personeelsvoorziening in de publieke sector. Verwacht wordt dat de knelpunten in de personeelsvoorziening op de arbeidsmarktsegmenten waarop de overheids- en onderwijssectoren hun personeel werven relatief groot zullen zijn. Het is daarom van groot belang dat de arbeidsmarktparticipatie van oudere werknemers in de publieke sector wordt gestimuleerd en dat oudere werknemers hun productiviteit behouden. Dit vereist een goed active ageing beleid van de werkgevers in de publieke sector dat gericht is op de duurzame inzetbaarheid van het oudere personeel dat hen motiveert om langer door te werken. Het spreekt voor zich dat een dergelijk active ageing beleid zich niet louter op het oudere personeel concentreert, maar ook de jongere cohorten voorbereidt op een veel latere pensioenleeftijd dan de afgelopen jaren het geval was.

In dit rapport is ingegaan op de vraag in welke mate werknemers reageren op de afschaffing van de FPU en in hoeverre de organisaties binnen de sector overheid en het onderwijs succesvol zijn in het stimuleren van het (productief) langer doorwerken van hun werknemers. Er is daarbij gekeken naar de mogelijke negatieve effecten van het versoberen van pensioenrechten op de productiviteit en werkmotivatie van oudere werknemers en hoe de gedragsreacties van werknemers verschillen.

Het blijkt dat het voeren van een goed active ageing beleid cruciaal is om langer doorwerken te stimuleren. De afschaffing van het FPU leidde tot een versobering in de pensioenrechten, waardoor werknemers 13 maanden langer moeten doorwerken om dit te compenseren. De verwachte pensioenleeftijd stijgt als gevolg van de afschaffing van de FPU echter slechts met drie maanden. In reactie op de versobering van 
hun pensioenrechten zijn werknemers namelijk meer gaan participeren in de levensloopregeling. Hierdoor slagen zij er in om hun pensionering toch weer naar voren te schuiven. Wel zijn werknemers in zowel de 1949 als in de 1950 groep sinds de financiële crisis pessimistischer geworden over het aantal maanden dat men eerder kan uittreden door hun levensloopbesparingen. Ook meer in het algemeen heeft de recente financiële crisis een substantieel effect gehad op de verwachte pensioenleeftijd. In 2009 en 2010 is voor beide leeftijdscohorten die we onderzoeken de verwachte pensioenleeftijd aanzienlijk toegenomen, waarschijnlijk als gevolg van het pessimisme dat is ontstaan door de economische crisis en de verslechtering van de dekkingsgraad van het ABP waardoor indexering van de pensioenen achterwege is gebleven en de onzekerheid over de hoogte van het toekomstige pensioen sterk is toegenomen. In 2010 denken beide groepen maar liefst ruim anderhalf jaar te werken dan dat ze in 2008 dachten.

Het jaar 2OIo is tevens het eerste jaar waarin er sprake is geweest van een grote uitstroom van werknemers naar de FPU. Deze groep vroeggepensioneerden heeft zeer specifieke kenmerken. Werknemers die in 20I0 op 6o-jarige leeftijd met FPU zijn gegaan verwachten een hogere pensioenuitkering, hebben meer dienstjaren bij de overheid of het onderwijs, zijn vaker laag opgeleid en zijn minder vaak getrouwd. Bovendien blijkt dat het grootste deel van de mensen die vervroegd uittraden werkzaam was bij provincies, gemeenten of bij de organisaties die vrijwillig zijn toegetreden bij het ABP. Daarbij geldt voor de eerste twee sectoren dat er naast de standaard FPU regeling nog aanvullende pensioenregelingen bestaan. Werknemers kunnen bijvoorbeeld bij de provincies gebruik maken de FPU-plusregeling die het FPU inkomen aanvult als werknemers met deeltijd-FPU te gaan. Dit verklaart ook dat meer dan helft van de werknemers die in het afgelopen jaar met FPU zijn gegaan een deeltijdpensioen heeft aangevraagd.

Uit onze analyses blijkt dat het vergroten van de financiële prikkels om langer door te werken door het verminderen van de pensioenrechten negatieve consequenties heeft voor de productiviteit van oudere werknemers. Werknemers die geboren zijn in 1950 en langer door moeten werken zijn in de afgelopen vijf jaar relatief minder tijd gaan besteden aan leidinggevende taken en supervisie van andere werknemers. Ook is men minder tijd gaan besteden aan meer complexe taken en besteden de werknemers met versoberde pensioenrechten tijdens hun werk minder tijd aan externe contacten met klanten of leveranciers.

Dit duidt er op dat werkgevers een personeelsbeleid voeren dat gericht is op het ontlasten van oudere werknemers die net niet meer vallen onder de oude pensioenregeling door belastende leidinggevende, complexe en communicatieve werkzaamheden uit hun takenpakket te halen. Het bestaan van een dergelijk ontziebeleid wordt bevestigd doordat we zien dat werknemers die in de 1950 geboren zijn minder werkstress ervaren en minder vaak overuren zijn gaan maken. ${ }^{17}$

17. Helaas hebben wij geen informatie over jongere cohorten. Het is echter aannemelijk dat de motivatie en de compositie van het takenpakket van jongere werknemers minder sterk is beïnvloed door de afschaffing van de FPU doordat zij meer mogelijkheden en meer tijd hebben om de schok in hun pensioenrechten op te vangen. 
De grootte van het negatieve effect van de afschaffing van de FPU verschilt echter sterk tussen werknemers. Het blijkt dat bepaalde persoonskenmerken van oudere werknemers belangrijk zijn voor hun reactie op de versobering van hun pensioenrechten. Daarbij is het zeer opmerkelijk dat juist de werknemers die meer bevlogen en gemotiveerd zijn in hun baan zich de versobering van hun pensioenrechten het sterkst aantrekken en het aantal onbetaalde overuren dat zij maken substantieel verminderen. Het feit dat vooral deze mensen het aantal onbetaalde overuren zo sterk verlagen wordt veroorzaakt door het gevoel oneerlijk behandeld te zijn. De werknemers die bevlogen en sterk negatief reciproque zijn - de mate waarin mensen onrechtvaardig gedrag van anderen willen bestraffen - reageren het sterkst op de schok in het pensioenstelsel. Opmerkelijk is daarbij dat de werkgever deze daling in werkinzet bewust of onbewust faciliteert door oudere werknemers te ontlasten in hun werk. In ieder geval blijkt dat werknemers ontevreden zijn over het personeelsbeleid en over de inzet die werkgevers leveren om hun langer in dienst te houden.

Een belangrijke conclusie die uit deze resultaten kan worden getrokken is dat een effectief personeelsbeleid dat de duurzame inzetbaarheid van het oudere personeel wil bevorderen niet uitsluitend gericht moet zijn op het geven van financiële prikkels om langer door te werken. Een daadkrachtig active ageing beleid is noodzakelijk om de demotiverende werking van deze financiële prikkels te compenseren en de productiviteit van oudere werknemers op peil te houden. Dit geldt specifiek voor het cohort werknemers dat direct geboren is na I januari 1950. Verwacht kan worden dat de demotiverende werking van de financiële prikkels kleiner wordt naarmate men jonger is.

\subsection{Aanbevelingen}

Zoals hierboven reeds werd aangegeven, leiden de resultaten van dit onderzoek tot een drietal belangrijke beleidsaanbevelingen voor de sector overheid en onderwijs. Hoewel soortgelijke informatie over andere sectoren grotendeels ontbreekt mag worden aangenomen dat verschillende van deze aanbevelingen ook voor andere sectoren van groot belang kunnen zijn:

- Sociale partners en werkgevers moeten meer aandacht besteden aan de productiviteitsagenda die gericht is op de werkmotivatie en duurzame inzetbaarheid van oudere werknemers die nodig is om hen in staat te stellen daadwerkelijk langer met de vereiste productiviteit door te werken. Immers, de werkinzet van oudere werknemers wordt negatief beïnvloed door de recente veranderingen in het pensioenstelsel, die louter gericht zijn op het vergroten van de financiële prikkel om langer door te werken. Relevant daarbij is dat dit active ageing beleid ook specifiek gericht moet worden op de meer bevlogen werknemers die doorgaans een sterke motivatie hebben voor hun werk en dat de traditie van het voeren van een ontziebeleid dat beoogt oudere werknemers te 
ontlasten van mentaal belastende taken dient te worden doorbroken, wanneer daardoor het werk ook minder interessant wordt.

- De levensloopregeling blijkt de werkenden met versoberde pensioenrechten in staat te stellen om toch nog aanzienlijk eerder met pensioen te gaan. Hoewel dit de scherpe kanten van de plotselinge noodzaak om langer door te werken vanwege de hervorming van het pensioenstelsel afhaalt, laat het ook zien dat de levensloopregeling faalt als beleidsinstrument om de duurzame inzetbaarheid van oudere werkenden te vergroten, Het kabinetsvoornemen om de levensloopregeling te vervangen door een vitaliteitsregeling lijkt hier enigszins op in te spelen, omdat de gespaarde middelen niet meer gebruikt kunnen worden om de arbeidsmarktuittrede te vervroegen. Wel kan het gebruikt worden voor de bekostiging van deeltijdpensionering. Dit laatste betekent echter wel dat werknemers die gebruik gaan maken van de vitaliteitsregeling in feite voor de keuze staan om de gespaarde middelen te gebruiken voor het volgen van scholing die hen in staat stelt langer productief door te kunnen werken of voor de bekostiging van deeltijdpensioen. De recente sterke toename in deeltijdpensionering laat zien dat dit voor veel oudere werknemers een aantrekkelijk perspectief is. Het betekent echter ook dat werkgevers moeten nadenken over de vraag hoe zij de inzetbaarheid van oudere werknemers zo optimaal mogelijk kunnen faciliteren.

- Wanneer sociale partners in de CAO-onderhandelingen en werkgevers in hun personeelsbeleid de komende jaren geen goed active ageing beleid van de grond krijgen, is de kans groot dat de voorgenomen verhoging van de AOW leeftijd tot dezelfde negatieve effecten op de inzet en productiviteit van werknemers leidt als de financiële prikkels die van de afschaffing van de FPU zijn uitgegaan. Uit ons eerdere onderzoek bleek dat mensen vooral bereid zijn om langer door te werken, wanneer er in de organisatie waarin ze werkzaam zijn:

- duidelijkheid is over de taken en bevoegdheden van het personeel in de organistatie,

- voldoende deskundig personeel beschikbaar is;

- een dynamische werkomgeving is;

- een goede sfeer met collega's is;

- medewerkers zelf het initiatief kunnen nemen voor hun loopbaanontwikkeling;

- medewerkers de nodigde cursussen kunnen volgen;

- medewerkers de capaciteiten hebben om snel nieuwe dingen te leren. 